\title{
Teleomechanism Redux? Functional Physiology and Hybrid Models of Life in Early Modern Natural Philosophy*
}

Charles T. Wolfe

\section{Summary}

The distinction between 'mechanical' and 'teleological' has been familiar since Kant; between a fully mechanistic, quantitative science of Nature and a teleological, qualitative approach to living beings, namely 'organisms' understood as purposive or at least functional entities. The beauty of this distinction is that it apparently makes intuitive sense and maps onto historico-conceptual constellations in the life sciences, regarding the status of the body versus that of the machine. I argue that the mechanism-teleology distinction is imprecise and flawed using examples including the 'functional' features present even in Cartesian physiology, the Oxford Physiologists' work on circulation and respiration, the fact that the model of the 'body-machine' is not a mechanistic reduction of organismic properties to basic physical properties but is focused on the uniqueness of organic life; and the concept of 'animal economy' in vitalist medicine, which I present as a 'teleomechanistic' concept of organism (borrowing a term of Lenoir's which he applied to nineteenth-century embryology) - neither mechanical nor teleological.

Keywords: Teleomechanism, mechanism, teleology, vitalism, physiology

\footnotetext{
* Earlier versions of this paper were presented at the Workshop on Early Modern Medicine and Natural Philosophy, Center for Philosophy of Science, University of Pittsburgh (May 2011); the seminar on Research Methods in History and Philosophy of Science, Ghent University (October 2011); the workshop on Life Sciences and Philosophy in the late $18^{\text {th }}$ century, IHPST, Paris (January 2012) and HSS, Philadelphia (July 2012). Thanks in particular to Peter Distelzweig, Benny Goldberg, Philippe Huneman and Alan Salter for comments and for sharing their work.
}

Charles T. Wolfe, Department of Philosophy and Moral Sciences, Sarton Centre for History of Science, Ghent University, Blandijnberg 2, B-9000 Ghent (charles.wolfe@ugent.be) 


\section{The problem of early modern teleomechanism}

We have been accustomed at least since Kant and the ensuing consensus in the history of philosophy to distinguish between the 'mechanical' and the 'teleological'; between a fully mechanistic, quantitative science of Nature exemplified by Newton (or Galileo, or Descartes) and a teleological, qualitative approach to living beings ultimately expressed in the concept of 'organism' - a purposive entity, or at least an entity possessed of inherent functional properties. The beauty of this distinction is that it seems to make intuitive sense and to map onto historical and conceptual constellations in medicine, physiology and the related natural-philosophical discussions on the status of the body versus that of the machine. From von Wright to Nagel (with Polanyi as a mirror image, presenting as negative what others present as positive) mechanistic versus teleological explanations are always presented as crucial, including as regards the scientific understanding of life. ${ }^{1}$

I argue that the distinction between mechanism and teleology is imprecise and flawed, on the basis of a series of cumulative examples: (i) the presence of 'functional' or 'purposive' features even in Cartesian physiology; (ii) the usage both therein and in the 'Oxford physiologists' of notions such as the 'office' (officium) of particular organs; (iii) the fact that the model of the 'body-machine', as in La Mettrie, is not at all a mechanistic reduction of organismic properties to basic physical properties but on the contrary a way of emphasizing the uniqueness of organic life; and (iv) the concept of 'animal economy' in vitalist medical theory, which I present as a 'teleo-mechanistic' concept of organism (borrowing a term of Timothy Lenoir's which he used to discuss nineteenth-century embryology) - neither mechanical nor teleological.

Again, the distinction between teleological models and explanations, and mechanistic models and explanations of living beings is familiar and apparently historically robust. But scholars have often maintained that the distinction is of little use in making sense of historical texts - and yet, early modern natural philosophy is consistently presented as the heyday of mechanism (even if some writers have moved away from a monolithic, somewhat ahistorical conception of mechanism towards a more pluralistic conception). ${ }^{2}$ Contrary to this narrative of triumphant mechanical purism, scholars such as Gaukroger, Osler, and Lennox have noted either the irreducibility of teleological analyses in representative early modern natural philosophers

1 Wright 1971, 2; Polanyi 1969, 157.

2 Contrast Dijksterhuis 1963 with, e.g., Gabbey 1993, Des Chene 2005 and Keller 2010. 
(e.g. Boyle, Gassendi) or a more discreet presence of functional explanatory concepts in self-proclaimed mechanists such as Descartes.

A different way of challenging the clarity or exactness of the traditional distinction emerges when we consider that early modern automata were indeed models of Life - that is, not attempts to deny or eliminate the specificity of Life and its inherent functional properties but rather to model it! Referring to eighteenth-century automata such as Vaucanson's duck, I have noted elsewhere, as has Jessica Riskin, that such constructions were not intended so much to 'demystify' or 'reduce' living entities to a set of neutral, inert mechanisms, as to assert the irreducibility of both: "The defecating Duck and its companions commanded such attention, at such a moment, because they dramatized two contradictory claims at once: that living creatures were essentially machines and that living creatures were the antithesis of machines." 3

And, moving onto early nineteenth-century German biology, Timothy Lenoir proposed the influential category of 'teleomechanism' to explain attempts by embryologists like Blumenbach to overcome what Kant had posited as an insurmountable disjunct, between mechanical and teleological principles (some of this met with Kant's approval, leading to a separate problem of the extent to which this episode in early nineteenth-century biology can be said to be Kantian or not). The general Kantian idea which Lenoir calls teleomechanism is that, unlike in the rest of natural science where mechanical explanations must be pursued as far as possible, in the organic realm, purposive organization has to be assumed as given. ${ }^{4} \mathrm{~A}$ teleomechanist research program was explicitly present in early nineteenth-century German life science in fields such as physiology, systematic zoology and later embryology, with the idea of the Bauplan.

Here I take Lenoir's term 'teleomechanism' more generally as a 'marker' for a distinctive conceptual trait in early modern natural philosophy's attempts to respond to the challenge of explaining living, organic entities. In previous work I have focused either on the 'mechanism-friendly' dimensions of Enlightenment vitalism, or conversely, on the complexity and diversity of 'mechanism' faced with the challenge of explaining living beings. I shall

3 Riskin 2003,610,612; on mechanisms and automata as responses to the challenge of explaining Life see Wolfe 2012a.

4 Lenoir 1982,30,113 (he then suggests further subdistinctions, notably, Kant and Blumenbach versus Kielmeyer, von Baer et al.: the latter group allows for teleological principles to play a causal role in mechanistic science; Lenoir 1982,126). The extent to which Kant could actually have accepted Blumenbach's vision of teleological principles as real causes of order in organisms - not merely as regulative (or as we might say, heuristic) principles - has been questioned by Richards 2000 and Zammito 2012, who thus challenge Lenoir's account (see also Huneman 2006). This does not affect the concept of teleomechanism as I am borrowing it from Lenoir. 
suggest teleomechanism as an indicator of the conceptual space that both lies between and unifies these two other approaches.

I first present a schematic overview of the early modern naturalphilosophical landscape, as regards mechanistic and teleological models of Life and their increasing complexification, from Descartes and Harvey, onto Fontenelle and Leibniz. It is not exhaustive, as I do not try and catalogue what every major figure said about mechanism (witness the absence of Locke and Hobbes), nor what every such figure said for or against final causes (witness the absence of Bacon or Spinoza), but rather focus on the attempts to combine the two in the conceptualising of living beings. Nor do I immediately propose working definitions of mechanism and teleology prior to the examination of specific cases, as none would fit all of my examples. In the next section I turn to the interplay between vitalist and materialist models of Life in the $18^{\text {th }}$ century as displaying a well-articulated series of teleomechanist conceptions, before concluding.

\section{Hybridizing mechanism - or, the hybridity of mechanism}

Iatromechanism is generally taken to be a kind of 'Galileanism of life': an attempt to quantitatively inscribe physiological phenomena within a Galilean mechanistic scheme; but in fact, the various, apparently pure statements of iatromechanism mask a more complex (and concrete) reality on the ground, where functional dimensions are never wholly absent from physiological explanations - even Descartes will speak of the "office" of the liver. ${ }^{5}$ Teleological language is present in the Discourse on Method itself (part V):

Then, too, we know from this that the true function (usage) of respiration is to bring enough fresh air into the lungs to cause the blood entering there from the right-hand cavity of the heart, where it has been rarefied and almost changed into vapors, to thicken into blood again before returning to the left-hand cavity. ${ }^{6}$

Thus it makes sense that even Descartes himself is increasingly seen as having a more complex physiology than what we would expect from the classic opposition between 'mechanism' and 'teleology'. The neat conceptual clarity of this opposition does not match up with the historical and experimental context well at all. As Gaukroger has observed, Cartesian mechanistic physiology, far from denying the existence of goal-directed processes, is in fact replete with functional language, e.g. when discussing the circulation of

5 Descartes to Elisabeth, May 1646, AT IV, 407.

6 AT VI, 53; CSM 1985, 138. 
blood and the motion of heart; the Cartesian point is not that bodies actually are machines (an eliminativist view, as Gaukroger puts it) but rather that the structure and behaviour of bodies are to be explained in the same way that we explain the structure and behaviour of machines (a reductionist view). ${ }^{7}$ And this 'reductionist' view is compatible with a variety of teleomechanical hybrids as I describe below.

Descartes thus also seems less far removed from someone we think of as more of an 'iatrochemist', the neuroanatomist Thomas Willis, who frequently uses terms like 'office', including several times in the Preface to his classic De cerebri anatome (1664): "Therefore thenceforward I betook my self wholly to the study of Anatomy: and as I did chiefly inquire into the offices and uses of the Brain and its nervous Appendix [i.e. the spinal cord]." ${ }^{8}$ When he describes his professorship ("the Province, which I hold in this Academy"), Willis explains that it required him to discuss "the Offices of the Senses, both external and also internal, and of the Faculties and Affections of the Soul, as also of the Organs and various provisions of all these [...]."

William Harvey, too, speaks in his discussion of generation of "the uterus of the hen and its office [...]," unsurprisingly for someone who explicitly uses teleological language, however much Descartes promoted him in the Discours de la méthode to a key plank in his mechanism (a significant chunk of part 5 features Harvey, who Descartes refers to as "an English physician"; Harvey is praised for the discovery of circulation and is described, in the French version, as "the first to break the ice", but Descartes disagrees as to the functioning of the heart, viewing it as a more passive organ which receives a good deal of its 'activity' from the heat of the blood).$^{10}$ Some scholarship has focused on who is the more consistent mechanist in this respect, but in any case Descartes' mechanistic appropriation of Harvey's discovery together with the more extended discussion by Dutch physicians - had a lasting impact, being repeated as an assessment (and interpretation) in the $18^{\text {th }}$ century, e.g. in the article "Méchaniciens (Médecine)" in the Encyclopédie, and in a classic paper by T.H. Huxley on the history - and fortune - of mechanistic conceptions in biology, in the later $19^{\text {th }}$ century. ${ }^{11}$

7 Gaukroger 2000. Osler tends to rely on the older view that if final causes were still present in Descartes despite his stated intention to ban them from physics, this was a sign of "unexpunged Scholastic" elements (Osler 2001,155-156); recent work on the 'embodied Descartes' offers a different view. From Descartes onto Boerhaave and later Haller, the interplay between mechanistic and teleological notions is more explicit still.

8 Willis 1681, 53f.; Willis 1664, sig. a2r; emphasis mine.

9 Harvey 1651/1981, ex. XIII, 83.

10 Descartes also mentions Harvey in the Passions de l'âme and Description du corps humain. 11 Huxley 1874. 
Harvey's analysis of the action of the heart in a wide range of organisms implied that he could identify a range of structurally dissimilar entities there is no structural similarity between the shrimp's heart and that of the chicken - which were recognized as 'hearts' principally by their performance of a common function. But this does not make Harvey some kind of residual Ancient, however much he says Aristotle is his "leader" $(d u x)^{12}$; his teleology, whether it is post facto or intrinsic, is also inherently modern. To be sure, Harvey is not just a partisan of 'weak teleology' in the sense in which some writers have sought to reconstruct Aristotle as a contemporary functionalist in the philosophy of mind, ${ }^{13}$ he is someone who thinks that 'ends' matter in a stronger sense. ${ }^{14}$ Yet at the same time, final cause in Harvey's eyes plays only a weak role in discovery. It may be suggestive to lines of inquiry but only when, for the most part, it can draw on evidence such as description from observation or experiment to suggest or demonstrate the action of a part or process. In a letter to Caspar Hoffman, an opponent of the idea of circulation, in May 1636, he wrote:

I merely assert that the movement of the blood from the heart through the arteries into the whole body, and likewise from the body through the veins back to the heart, is carried on continuously and without interruption [...]. But [...] about the causes of this movement and circulation, particularly about its final cause, I have never spoken but have omitted it altogether, deliberately $[\ldots]$ you $[\ldots]$ complain that I am a poor Anatomist and a poor Analytical Philosopher, because I try to investigate the phenomenon itself without having established the wherefore [...] I add to the phenomenon nothing but the general account of it, [...] no physiological speculation, no cause over and above, nor [do I] speculate for what reason Nature should give this movement to the blood by means of the beating of the Heart. ${ }^{15}$

12 In the Preface to De Generatione Animalium Harvey calls Aristotle his general (dux) and Fabricius his guide (praemonstrator): Harvey 1651/1981, 20.

13 Nussbaum/Putnam 1992.

14 He uses Aristotle's language of "for the sake of" (in Latin, cuius gratia) rather than "final cause". I am grateful for the helpful and interesting discussions on Harvey and teleology I have had with Peter Distelzweig, Benny Goldberg and James Lennox. I have also benefited greatly from Distelzweig 2011, Goldberg 2011 and Salter 2010.

15 Harvey, "To Caspar Hoffman", Appendix One in Whitteridge 1971. Granted, it is not selfevident that the centrality of teleology in Harvey should be decided (or not) on the basis of the role it plays in discovery. Yet, thinking e.g. of Boyle, one would expect a self-conscious 'teleologist' in natural philosophy to make active use of the concept as a way of indeed producing discoveries in nature (thus Aristotle on teeth growth, or Darwin's correspondent Asa Gray on the vertebrate eye). Peter Distelzweig has very carefully analysed Harvey's Prelectiones anatomiae (his Lumleian Lectures) in support of a teleological reading, and points to the presence of functional vocabulary - usus and actiones - in the very first sentence: "Anatomia est facultas quae occulari inspectione et sectione partium usus et actiones" ("Anatomy is the faculty of knowing the actions and uses of the parts by employing visual inspection and dissection," Harvey 1964, 4). I agree that this is functional vocabulary, but do not find that it justifies the reading of Harvey as a teleologist in a stronger sense. However, my only concern here in this paper is to note the presence of an 'emergent teleomechanism' in Harvey, not to come to a stand on the (in my view irresolvable) question of whether Harvey is a teleologist or not. 
The 'what is it for?' approach is a legitimate tool of inquiry but so too are analogy or comparative anatomy, neither of which play any necessary or formal role in inquiry for Harvey (although analogical relations between parts of different animals, such as shrimp and chicken hearts as mentioned above, are important). François Duchesneau has described Harvey's method in De motu cordis as an "analytic teleology", ${ }^{16}$ i.e., a post facto reconstruction of a teleology that is meant to explain the role of each organ - thus a species of explanatory (rather than metaphysical) teleology.

We thus need to distinguish between a 'teleomechanist' type of complex description or 'systems' description ('structuro-functional' explanation in Wolfe/Terada 2008), and an outright teleological explanation. It does seem that Harvey rejects, or is cautious with respect to the latter (except in $D e$ generatione where he - like many an observer of generation - is more willing to entertain teleological hypotheses). He lets himself be appropriated in this direction, which is not the same thing as incorporating such concepts in his own explanatory scheme; the locus classicus of such appropriation is a famous comment of Robert Boyle's:

When I asked our famous Harvey [...] what were the things that induced him to think of a circulation of the Blood $\mathrm{He}$ answered me, that when he took notice that the valves in the veins of so many several parts of the body, were so placed that they gave free passage to the blood towards the heart, but opposed the passage of the venal blood the contrary way: he was invited to imagine, that so provident a cause as nature had not plac'd so many valves without design. ${ }^{17}$

Notice that Boyle is not just trumpeting design and summoning Harvey in service of this project; he is emphasizing that the notion of design actively helped Harvey in his experimental work. While my intention is not to simply call for a reevaluation of the importance of teleology in early modern science, ${ }^{18}$ just as I did not want to centrally focus on the reevaluation of the complexities of mechanism, it seems unavoidable to call attention to its central presence in Boyle - undoubtedly the best-known teleologist in early modern science; he would have preferred to be called a friend of final causes - and his peers.

Boyle stresses the 'utility' of final causes in natural-philosophical explanations (it is possible for someone to say all of this beautiful handiwork vertebrate eyes, finches' beaks, lungs and teeth and so on - is the sign of a Designer) while also noting that all scientific explanations must rely on efficient causes. Thus in the Christian Virtuoso, he acknowledges that, "To be

16 Duchesneau 1998, conclusion.

17 Boyle 1772/1968, V, 427; see discussion in Bylebyl 1982.

18 See Osler 2001, Lennox 1983 for a historical corrective and Fuchs 2001, Sloan 2007 for more normative statements of the importance of teleology. 
told that an eye is the organ of sight, and that this is performed by that faculty of the mind which from its function is called visive, will give a man but a sorry account of the instruments and manner of vision itself, or of the knowledge of that Optificer, who, as the Scripture speaks, 'formed the eye".${ }^{19}$ And in the Disquisition: "the naturalist should not suffer the search, or the discovery of a Final Cause of Nature's works, to make him under-value or neglect the studious indagation [investigation] of their efficient causes. ${ }^{20}$ But there is no deliberate hybridization of two models here; rather, there is the insistence that mechanism and design go well together, which is not teleomechanism.

Harvey's caution compared to Boyle's appropriation of him does not make him, mutatis mutandis, a perfect specimen of teleomechanism as something 'emergent' here; but it means we need to be discerning when attributing 'teleological' views to these figures. As Alan Salter has noted, forty years after the publication of De Motu Cordis, when the physician Richard Lower, a onetime Oxford colleague of Harvey's, sought to extend the Harveyan project on circulation, Lower made very much this sort of distinction. For instance, in Chapter 1 of his Tractatus de Corde, we read that

I must preface my account of [the movement of the blood] by some remarks on the Position and Structure of the heart. When these have been duly considered and collated, it will be easier to grasp how carefully both its Fabric and Position are adapted for movement, and how fittingly everything is arranged for the distribution of the blood to the organs of the body as a whole. ${ }^{22}$

The two steps Lower recommends - ascertain position and structure, then 'grasp' fabric, position, and 'fittingness' - match up with the distinction I suggested above, between a teleomechanistic explanation understood as employing a weaker, explanatory teleology and an outright teleological explanation in the stronger, ontological sense (e.g. design in Boyle and 'fittingness' in Lower).

Harvey seems both to employ the former kind - explanatory, analytic or heuristic - of teleological explanation, while, e.g. Lower stands for something closer to Galenic, 'actual' or 'directed' teleology. ${ }^{22}$ Yet Harvey often tries to be agnostic here, and does not seem overly keen to be viewed as a 'modern' protagonist of the New Science: rather than proclaiming his 'modernity' like

19 Boyle 1772/1965, V, 516.

20 Boyle 1772/1965, V, 411.

21 Lower 1669/1932, 2. Thanks to Alan Salter for this.

22 Von Staden suggests that Galen subscribes to a "genuine" teleology, not a "merely heuristic teleology" (von Staden 1997, 197); Galen often emphasizes that his predecessors failed to see that any explanation of the function of the parts must be thoroughly teleological. Following Hankinson 1989, one can say that Galen - like Plato and unlike Aristotle - follows a "directed" or "intentional" teleology. 
Hobbes, Bacon or Descartes, he calls the neoterics "shitbreeches". ${ }^{23}$ This syncretistic character of Harvey's position and the way it can be appropriated more teleologically (Boyle, Lower), mechanistically (Descartes) or in other ways, is itself an indicator of what I term the hybridity of teleomechanism: a synthetic capacity, which produces an entirely immanent explanatory model, without levels or ontological differentiations.

Indeed, even Boyle, if viewed more in the light of the mechanics of the body and less of design or rational teleology, belongs to a diverse sub-set of thinkers including Claude Perrault, Gassendi, Fontenelle and Leibniz, who seek to articulate a model of the human body that combines the best insights of the mechanical theories but also chemical theories. ${ }^{24}$ Boyle refers to the human body as a "compound engine, such as mechanicians would call hydraulicpneumatical" and elaborates on this by pointing to the "spirits, vital and animal", the "little springy particles" and "things analogous to local ferments", all of which "are not to be discerned in a dead body". ${ }^{25}$ But we encounter a first full-blown form of teleomechanism with Fontenelle and Leibniz.

Earlier I recalled how mechanism - Cartesian and other - is more complex than the straw man of iatromechanism. This is the case both in its "canonical forms' (from Descartes to Boyle to Boerhaave) and, less surprisingly, in its later more complex forms such as Haller's physiology. Similarly - in a kind of parallel - iatrochemical explanations such as those found in Willis and Stahl blend, if not seamlessly, quantitative and qualitative definitions of fermentation, such that one no longer knows what is a strictly particulate explanation versus one on which invokes 'liquors' ,juices', 'heat' and so forth. Teleomechanism proper appears when all these models are deliberately combined. Consider for instance this elegant statement on the body from Bernard de Fontenelle in 1707, ostensibly in the context of a discussion of the pituitary gland:

The human body considered in relation to an infinite number of voluntary movements it can perform, is a prodigious assemblage of Levers pulled by Ropes. If one considers it in relation to the motion of the liquors it contains, it is another [sort of] assemblage of an infinite number of Tubes and Hydraulic Machines. Finally, if one examines it in relation to the production of these liquors, it is an infinite assemblage of Chymical Instruments or Vessels, Filters, Distillation Vats, Receptacles, Serpentines, etc. [...] The greatest Chemistry apparatus of all in the human Body, the most wonderful Laboratory is in the Brain, from whence this Extract of the blood is drawn known as Spirits, the sole material motors of the entire Machine of the Body. ${ }^{26}$

23 "He [Harvey] bid me to goe to the Fountain-head, and read Aristotle, Cicero, Avicenna, and did call the Neoteriques shitt-breeches" (John Aubrey, Brief Lives, cited in French 1994, 220).

24 Azouvi 1982.

25 Boyle 1772/1965, V, 422; Lennox 1983, 52.

26 Fontenelle 1707/1730,16, my translation. 
If we take teleomechanism in this more specific sense, not just of the presence of disparate elements - mechanistic and purposive, or iatromechanical and iatrochemical - in a given text, but to mean a deliberate grafting together of these elements with a synthetic intent, an even more overt case would be Leibniz. Where Boyle had defined the body as a hydraulico-pneumatic machine (comparable as it were to Fontenelle's hydraulico-chemical machine), Leibniz goes one step further, presenting the body as a hydraulicopneumatico-pyrotechnic machine..$^{27}$ In order to explain the functions of the body,Leibniz appeals to an idea of final causation, which he claims, is essential to the description of any machine:

The human body, like the body of any animal, is a sort of machine. Any machine moreover is best defined in terms of its final cause, so that in the description of the parts it is therefore apparent in what way each of them is coordinated with the others for the intended use. ${ }^{28}$

Thus, like Boyle and unlike the received view of Descartes, Leibniz embraces teleological explanations of the functions of the extended body of animals and humans, due to his overall pessimism regarding the possibility of fully explaining bodily functions mechanistically: "The organism of animals is a mechanism which supposes a divine preformation. What follows upon it is purely natural and entirely mechanical."${ }^{29}$ In both Boyle and Leibniz, the teleology at work is more metaphysically foundationalist than, notably, in Harvey or Fontenelle. But in all these cases we have seen a rough hybridity at work, manifest in diverse articulations of the mechanical and the chemical, the mechanical and the functional, and of course a myriad sorts of teleology, all of which are compatible with or supervene upon mechanistic explanations. But the fullest teleomechanist synthesis of these trends, in a more 'immanent' vein, appears in the interplay between materialism and vitalism in the eighteenth century (particularly in the latter).

\section{Vitalism as expanded mechanism}

The term 'vitalism' is still frequently used, in both the history of the life sciences and contemporary philosophy of biology to indicate something which lies outside the boundaries of respectable science, and also as a quasi-synonym of 'teleology' understood as a metaphysically foundationalist invocation of final causes. Conversely, materialism is frequently defined as a

27 Fichant 2003, Smith 2007.

28 Leibniz, Corpus hominis et uniuscujusque animalis Machina est quaedam, 1680-1683, trans. J. Smith, in Smith 2007, 151.

29 Leibniz, Fifth Letter to Clarke, § 115, in Clarke 1738/1978, vol. 4, 667. 
direct opposite of vitalism; it is treated as a quasi-synonym of 'mechanism' (despite Descartes or Boyle's anti-materialism, and Diderot's anti-mechanism, to name some obvious cases). This is still the case in a recent entry in a major reference source, in which we are told that "materialists explain everything in terms of matter and motion; vitalists, in terms of the soul or vital force". ${ }^{30}$ The various ways, historical and conceptual, medico-biological and metaphysical, in which this is a false opposition, make for an interesting story but not one that belongs here. Rather, I wish to show how both materialism and vitalism, considered now in some representative 18th-century cases, are moments of teleomechanism. I shall discuss each of these in turn.

$18^{\text {th }}$-century materialism has frequently been presented as 'mechanistic'. In fact, eclecticism (or what I have called hybridity) is the norm here, and for our purposes it is noteworthy that materialists such as Julien Offray de La Mettrie (despite the set of associations that are conjured up by his most famous title, L'Homme-Machine) also have a highly 'embodied', not strictly mechanistic conception of the body-machine. ${ }^{31}$ La Mettrie's medical materialism combines mechanistic language - indeed, the most classic mechanist metaphor, clockwork - with properties (chemical, organizational, etc.) that machines do not possess:

The body is but a clock, whose clockmaker is the new chyle. Nature's first care, when the chyle enters the blood, is to excite in it a kind of fever which the chemists, who dream only of furnaces, had to construe as fermentation. This fever produces a greater filtration of the spirits, which mechanically animate the muscles and the heart, as if they had been sent there by order of the will..$^{32}$

Indeed, for La Mettrie "Man is so complex a machine (une Machine si composée) that it is impossible to get a clear idea of the machine beforehand, and hence impossible to define it". ${ }^{33}$ The machine here becomes an entity with an internal principle of organization, which empirically is a 'mechanico-chemical' hybrid, and conceptually is more 'structural-functional' than the classic, restrictive picture of mechanism (and as we saw, even in Descartes the reality is less restrictive than the reputation).

Diderot sometimes uses machine metaphors in writing about the body, but much more rarely than La Mettrie, and in that sense he is less of a teleomechanist, understood as someone for whom the explanation of the living body requires an integration of mechanical and teleological models. Whereas La Mettrie is indeed interested in the organic, living body as a 'basement level', something ontologically irreducible (not in the sense that he does not

30 Wellmann 2003.

31 Wolfe 2012b.

32 La Mettrie 1987, I, 105; see Pépin 2011.

33 La Mettrie 1987, I, 66-67. 
accept reductionist, componential explanation but in the sense he is not a genuine, restrictive mechanist); but he is interested in exploring the boundary levels in between body and machine, or machine and organism. As François Pépin has put it: "La Mettrie aime jouer avec les plus et les moins de la machine." ${ }^{34}$ Diderot, in contrast, is fascinated with more complex machine metaphors for organism such as the loom and the vibrating chords of a harpsichord, to which he adds a variety of chimiatric concepts, ${ }^{35}$ stressing for instance that "the human body is a system of actions and reactions". ${ }^{36}$ And he is both influenced by and in interaction with the conceptual production of vitalist medicine. ${ }^{37}$ What do we find if we turn to vitalism?

The word 'vitalism' may have been first used to describe the doctrines of the Montpellier medical faculty in the $18^{\text {th }}$ century. ${ }^{38}$ The Montpellier vitalists overtly try and position their 'doctrine' as a 'neither-nor' in between the two strongly opposite positions of mechanism and animism. Bordeu, Ménuret, Fouquet, Barthez in different ways and with different emphases, criticize mechanism - whether Italian iatromechanism, Descartes, Boerhaave or even Haller (who is of course already something of a hybrid figure in terms of 'strict mechanism') for its lack of attention, or explanatory weakness faced with the 'fact' of living, embodied agents, which require specific types of explanations. But symmetrically, they criticize the animism of G.E. Stahl for its lack of explanatory power, period, since it is a form of 'supernaturalism', in which "the life of the soul consists [...] particularly in action exercised and carried out in a body, by means of a body, on and affecting bodily activities" ${ }^{39}$ (This is not true of their mentor Sauvages.)

Using perfectly teleomechanical language, Barthez says that "mechanics" is useful for determining exactly what "the advantages of the living body's organs are, in the mechanism of its intended functions" ${ }^{40}$ Bordeu refers to the 'evident fact' that animal bodies are not like watches because they are self-winding, and comments that unfortunately the Stahlians took this to mean that the higher-level features of vitality (fighting off illness and maintaining stability in the body, whether its temperature, digestive system, etc.) are dependent on the soul. ${ }^{41}$ Ménuret appeals in reductionist fashion to a fairly basic, indeed 'base' level of bodily dysfunction - inflammation of the

34 Pépin 2011, 266.

35 Cheung 2010.

36 Diderot 1975-, XVII, 337.

37 Kaitaro 1997.

38 Wolfe/Terada 2008.

39 Stahl 1859, § LII, 298.

40 Barthez 1858, 37.

41 Bordeu 1751, § CXXXI, 1818, vol. 1, 204. 
lower intestine - in order to challenge animism, and suggests that we would "laugh at an animist or Stahlian who would argue that this illness is a gift of Nature or the soul". ${ }^{42}$

The relevant concept here, as I have discussed elsewhere, is the 'animal economy', which is fully articulated teleomechanism, as it is both organismic (as in the key metaphor of the beeswarm ${ }^{43}$ ) and also subserved by a variety of mechanistic explanations. The vitalist Louis de La Caze describes his aim as the explanation of "the mechanism which subserves the functions of the animal economy", a mechanistic level "chiefly founded on anatomical observations" ${ }^{44}$ Ménuret speaks in rather hybrid terms of "l'organisation animée de notre machine". ${ }^{45}$ Similarly, Buffon, the theorist of "organic molecules", comfortably speaks in the same sentence of "animal economy" and "machine", or "la mécanique vivante" and "le mécanisme de l'économie animale" ${ }^{46}$ conversely, 'machine' was frequently used to mean 'body'.

Examples of medical areas requiring these hybrid, teleomechanist analyses include sphygmology (the medicine of the pulse) and, as a particular organ, the glands. Bordeu is often described as having selected the glands as his theoretical object because they are the exemplar of what is non-mechanistic about the animal economy, since all mechanistic physiologies stumble, not on the humours the glands extract from the blood, but on the workings of the secretory organs themselves: for instance, how does a gland differentiate between one fluid and another, given that they are clearly 'intended' to deal with specific fluids and not others? Humours, Bordeu says, cannot be explained according to "the actions of solids and the disposition of the organs". ${ }^{47}$ But at the same time he doesn't want to fall back on a chimiatric explanation of humours, just to emphasize that pure mechanism can't account for them. The distinctively Bordevian emphasis here is on the 'sensitivity' of each gland (which works like a force). Now, to achieve this level of analysis the glands have to be studied according to "position and interconnections, in order to know their action" (46): there is the structuro-functional analysis encapsulated in a sentence; but it is not superfluous to note that Bordeu continues, "this is indeed part of Anatomy" (emphasis in original). Simply, the scope of "anatomical inquiry" must be widened, Bordeu argues, to include "the use of the parts, their interplay, connections and relations". This is what he means

42 "Ténesme", Enc. XVI, 137a.

43 Wolfe/Terada 2008, Wolfe 2009.

44 La Caze 1755, 2.

45 Enc. XIII, 239.

46 Buffon 1753, 3-4; article "Histoire naturelle", Enc. VIII, 226 b.

47 Bordeu 1751, Preface, in Bordeu 1818, vol. 1, 48. 
by "animating the skeleton of anatomy" ${ }^{48}$ Indeed, Bordeu, here as elsewhere, is less 'anti-mechanistic' than he is an 'expanded mechanist', performing experiments by compressing a piece of sponge in the jaws to study how a gland reacts to compression by muscular tissue.

Unlike the Oxford physiologists, for Bordeu it is not the structure and position of organs which has to be ascertained so that a higher teleology can be ascertained - a higher level of intelligibility and/or a Design as in Boyle. Rather, there is an immanent level of "position [...] interconnections [...] use of the parts $[\ldots]$ their interplay, connections and relations" ${ }^{49}$ : teleomechanism.

\section{Conclusion}

I have sought to reconstruct a concept of teleomechanism in early modern and Enlightenment natural philosophy (with a particular emphasis on medical theory and physiology), which minimally shows the following:

First, that mechanism and antimechanism, while they may possess an enviable intellectual clarity as conceptual constellations, are in fact impossible to separate or historically define in isolation from one another. Supposedly pure mechanistic models exhibit sensitivity to functional properties (from Descartes and Boerhaave straight down to Haller's 'micromechanism'); supposedly antimechanistic models such as the positions here referred to as 'vitalist' exhibit a greater recognition of the role, pertinence and validity of mechanical explanations of particular phenomena than is generally believed.

Second, that the forms of teleology we encounter in the above analyses are 'explanatory' rather than 'ontological' - attempts to respond to the challenge of explaining living bodies rather than assertions of an inherent and overarching finalistic structure of the world; thus even prior to the organismic or organizational models of living being presented under names such as the 'animal economy', these earlier teleologies are already reasonably close to a Lenoirian kind of teleomechanism.

Thirdly (hence), teleomechanism here is neither a claim of total ontological closure as is sometimes associated with mechanism (compare Gabbey's comment that $17^{\text {th }}$-century mechanism "tried to explain everything,

48 Bordeu 1751, Preface, in Bordeu 1818, vol. 1, 46 - a formulation curiously recalling Haller's description of physiology as "animated anatomy" ("Physiologia est animata anatome", Haller 1747, 5).

49 Bordeu 1751, Preface, in Bordeu 1818, vol. 1, 46. 
which was too much by a long chalk" ${ }^{50}$ ) nor a claim of regional ontological uniqueness where organisms have teleological features which differentiate them from mechanical nature overall. ${ }^{51}$ Instead, teleomechanism combines the model-making, reductionist component of mechanism and the pluralism (in the sense of the recognition of hierarchical plateaus of organization) of teleology. As we saw with the animal economy and its representative image, the bee-swarm, these analyses seek to articulate an idea of complex organization that integrates mechanical explanations. However - depending on how strong a teleology it incorporates - it can hold that mechanical explanations have limits, and thereby allow that "within the organic realm the various empirical regularities associated with functional organisms can be investigated". 52

In that sense, fourth, teleomechanism is quite contrary to the traditional distinction between mechanistic and organismic accounts of living beings, in which the former are usually presented as excluding crucial features of living organisms in order to achieve a complete model; as e.g. in the opposition between the reality of homeostatic processes and the 'mere' account of anatomical structures. ${ }^{53}$ Teleomechanism does not oppose the dynamism of homeostatic processes to the static character of anatomy: it seeks to unite them.

\section{Bibliography}

Azouvi, François, «Entre Descartes et Leibniz:l'animisme dans les Essais de physique de Claude Perrault», Recherches sur le XVII siècle 5 (1982) 9-19

Barthez, Paul-Joseph, Nouveaux éléments de la science de l'homme, $3 \mathrm{~d}$ revised edition, 2 vols. (Paris 1858)

Berryman, Silvia, "Ancient Automata and Mechanical Explanation", Phronesis 48:4 (2003) 344-369

Bordeu, Théophile de, Recherches anatomiques sur la position des glandes et leur action (Paris 1751)

Bordeu, Théophile de, Euvres complètes, précédées d'une Notice sur sa vie et ses ouvrages par M. le Chevalier de Richerand, 2 vols. (Paris 1818)

Boyle, Robert, The Works of the Honourable Robert Boyle, 6 vols., ed. T. Birch (London 1772; reprint, Hildesheim 1965)

50 Gabbey 1985, 13.

51 Berryman 2003,346. There is no space here to explore other scenarios in which mechanism is more heuristic than ontological, more partial than restrictive; or a more 'Kantian' teleomechanism viewed as implicitly recognizing a partial, 'regional' truth of mechanism. Both of these are subtly different from the immanent teleomechanism described here.

52 Lenoir 1981, 305.

53 Gierer 1996. 
Buffon, Georges-Louis Leclerc de, Histoire naturelle, générale et particulière IV (Paris 1753)

Bylebyl, Jerome J., "Boyle and Harvey on the Valves in the Veins", Bull. Hist. Med. 56 (1982) 351-367

Cheung,Tobias, “Omnis Fibra Ex Fibra:Fibre Architectures in Bonnet's and Diderot's Models of Organic Order", Early Science and Medicine 15 (2010) 66-104

Clarke, Samuel, The Works of Samuel Clarke, 4 vols. (London 1738; reprint New York 1978)

Descartes, René, Euvres, 11 vols., publ. par Charles Adam and Paul Tannery (Paris 1964-1976) (cited as AT followed by volume and page number)

Des Chene, Dennis, "Mechanisms of life in the seventeenth century", Studies in History and Philosophy of Biological and Biomedical Sciences 36:2 (2005) 245-260

Diderot, Denis, Euvres complètes, édition Herbert Dieckmann, Jacques Proust and Jean Varloot (Paris 1975-)

Distelzweig, Peter, Functional analysis and teleology in Descartes' physiology (ms., 2011)

Dijksterhuis, E.J., The Mechanization of the World Picture, trans. C. Dijshoorn (Oxford 1963)

Duchesneau, François, Les modèles du vivant de Descartes à Leibniz (Paris 1998)

Fichant, Michel, «Leibniz et les machines de la nature», Studia Leibnitiana 35 (2003) $1-26$

Fontenelle, Bernard de, «Sur la glande pituitaire», Histoire de l'Académie Royale des Sciences pour 1707 (Paris 1730)

French, Roger, William Harvey's Natural Philosophy (Cambridge 1994)

Fuchs, Thomas, The Mechanization of the Heart: Harvey and Descartes, trans. Marjorie Grene (Rochester 2001)

Gabbey, Alan, "The Mechanical Philosophy and its Problems: Mechanical Explanations, Impenetrability and Perpetual Motion", in: Joseph C. Pitt (ed.), Change and Progress in Modern Science (Dordrecht 1985) 9-67

Gabbey, Alan, "Between Ars and Philosophia Naturalis: Reflections on the Historiography of Early Modern Mechanics", in: J.V. Field/Frank A.J.L. James (eds), Renaissance and Revolution: Humanists, Scholars, Craftsmen, and Natural Philosophers in Early Modern Europe (Cambridge 1993) 133-145

Gaukroger, Stephen, "The resources of a mechanist physiology and the problem of goal-directed processes", in: Stephen Gaukroger/John Sutton et al. (eds), Descartes' Natural Philosophy (London 2000) 383-400

Gierer, Alfred, "Organisms-Mechanisms: Stahl, Wolff and the Case against Reductionist Exclusion", Science in Context 9:4 (1996) 511-528

Goldberg, Benjamin, 'Ex Naturae Libro Declarabimus': William Harvey and Natural Theology (ms., 2011)

Haller, Albrecht von, Primae lineae physiologiae in usum praelectionum academicarum (Göttingen 1747)

Hankinson, R.J., "Galen and the Best of All Possible Worlds", Classical Quarterly 39 (1989) 206-227

Harvey, William, Exercitationes de generatione animalium (1651), trans. and ed. Gweneth Whitteridge (Oxford 1981) 
Harvey, William, The Anatomical Lectures of William Harvey, trans. Gweneth Whitteridge (London 1964)

Huneman, Philippe,"Naturalising purpose:From comparative anatomy to the 'adventures of reason", Studies in History and Philosophy of Biology and Biomedical Sciences 37:4 (2006) 621-656

Huxley, Thomas H., "On the Hypothesis that Animals Are Automata, and Its History”, Nature 10:253 (1874) 362-366

Kaitaro, Timo, Diderot's Holism: Philosophical Anti-Reductionism and Its Medical Background (Frankfurt 1997)

Keller, Vera, "Drebbel's Living Instruments", History of Science 48:1 (2010) 39-74

de La Caze, Louis, Idée de l'homme physique et moral pour servir d'introduction à un traité de médecine (Paris 1755)

de La Mettrie, Julien Offray, Euvres philosophiques, 2 vols., ed. Francine Markovits (Paris 1987)

Lennox, James, "Robert Boyle's Defense of Teleological Inference in Experimental Science", Isis 74 (1983) 38-52

Lenoir, Timothy, "Teleology without regrets. The transformation of physiology in Germany, 1790-1847", Studies in History and Philosophy of Science 12 (1981) 293-354

Lenoir,Timothy, The Strategy of Life. Teleology and Mechanism in Nineteenth-Century German Biology (Chicago 1982)

Lower, Richard, Tractatus de Corde (1669), trans. K.J. Franklin, in: Robert T. Gunther (ed.), Early Science in Oxford, Vol. IX (Oxford 1932)

Nussbaum, Martha/Hilary Putnam, "Changing Aristotle's Mind", in: Martha Nussbaum/Amelie Rorty (eds.), Essays on Aristotle's 'De Anima' (Oxford 1992) 27-56

Osler, Margaret, "Whose Ends? Teleology in Early Modern Natural Philosophy", Osiris 16 (2001) 151-168

Pépin, François, "Lectures de la machine cartésienne par Diderot et La Mettrie", Corpus 61 (2011) (special issue: Matérialisme et cartésianisme) 257-280

Polanyi, Michael, “The Logic of Tacit Inference”, in: Marjorie Grene (ed.), Knowing and Being (Chicago 1969) 138-158

Richards, Robert, "Kant and Blumenbach on the Bildungstrieb: A Historical Misunderstanding", Studies in the History and Philosophy of Biology and the Biomedical Sciences 31 (2000) 11-32

Riskin, Jessica, "The Defecating Duck, or, the Ambiguous Origins of Artificial Life", Critical Inquiry 29:4 (2003) 599-633

Salter, Alan, William Harvey. A Study in Empiricism, PhD, University of Sydney, Unit for History and Philosophy of Science (Sydney 2010)

Sloan, Phillip R., "Teleology and Form Revisited", in: Richard Burian/Jean Gayon (eds), Conceptions de la science, hier, aujourd hui et demain. Hommage à Marjorie Grene (Brussels 2007) 343-367

Smith, Justin E.H., "The Body-Machine in Leibniz's Early Medical and Physiological Writings: A Selection of Texts with Commentary", Leibniz Review 17 (2007) 141-179

von Staden, Heinrich, "Teleology and Mechanism: Aristotelian Biology and Early Hellenistic Medicine", in: Wolfgang Kullmann/Sabine Föllinger (eds), Aristotelische Biologie: Intentionen, Methoden, Ergebnisse (Stuttgart 1997) 183-208 
Stahl, Georg Ernst, Disquisitio de mecanismi et organismi diversitate (1706), in: Euvres médico-philosophiques et pratiques de G.E. Stahl, trans. Théodore Blondin, ed. Louis Boyer, vol. 2 (Paris 1859)

Wellman, Kathleen, "Materialism and vitalism", in: John L. Heilbron (ed.), The Oxford Companion to the History of Modern Science (Oxford 2003) (Oxford Reference Online: http://www.oxfordreference.com, September 15 2011)

Whitteridge, Gwyneth, William Harvey and the Circulation of the Blood (London 1971)

Willis, Thomas, Of the Anatomy of the Brain [separately paginated], in:Thomas Willis, Practice of Physick, trans. Samuel Pordage (London 1681) (a translation of Cerebri anatome, 1664)

Wolfe, Charles T., «Organisation ou organisme? L'individuation organique selon le vitalisme montpelliérain», Dix-huitième siècle 41 (2009) 95-115

Wolfe, Charles T., «Le mécanique face au vivant», in: Aurélia Gaillard/Bernard Roukhomovsky/Sophie Roux (eds), L'automate: modèle, machine, merveille (Bordeaux 2012a) 115-138

Wolfe, Charles T., "Forms of Materialist Embodiment", in: Matthew Landers/Brian Muñoz (eds), Bodies of Knowledge: Anatomy, Complexity and the Invention of Organizational Systems, 1500-1850 (London 2012b) 129-144

Wolfe, Charles T./Motoichi Terada, "The Animal Economy as Object and Program in Montpellier Vitalism", Science in Context 21:4 (2008) 537-579

Wright, Georg Henrik von, Explanation and Understanding (London 1971)

Zammito, John H., "The Lenoir Thesis revisited: Blumenbach and Kant", Studies in History and Philosophy of Biological and Biomedical Sciences 43:1 (2012) 120-132 